Agropedology 2016, 26 (01), 79-86

\title{
Secondary and Micro Nutrient mapping in forest soils of Kandhamal district, Odisha
}

\author{
Bandita Jena", R.K. Nayak, Jyotirmayee Das, R.K. Parida and D. Sethi \\ Department of Soil Science and Agricultural Chemistry, Orrisa University of Agricultural and Technology, \\ Bhubaneswar, India
}

\begin{abstract}
Emergence of widespread secondary and micro nutrient deficiencies have become major constraints of productivity. Farmers give hardly any emphasis on application of these nutrients. As a result decline or stagnation in production and productivity of many crops is observed creating a huge gap between the requirement and supply of food grains. For efficient soil and crop management soil test based fertilizer application is highly essential. major nutrient analysis is often done micro nutrient analysis is usually neglected due to prohibitive costs and expensive instruments. Data on soil micro and secondary nutrients status were used for generation of soil fertility maps in GIS environment. In the present paper GPS based soil survey was conducted during 2012-13 where spatially distributed georeferenced soil samples $(0-20 \mathrm{~cm}$ depth) were collected from forest soils of Kandhamal district, Odisha and analysed for various secondary and micronutrients along with some basic parameters like $\mathrm{pH}, \mathrm{EC}$ and OC. Derived thematic maps showed deficiency of sulphur to an extent of $82.5 \%$ followed by boron and Zinc as the limiting elementing of Kandhamal soils.
\end{abstract}

Keywords: Nutrient mapping soil survey, forest soils

\section{Introduction}

Production and productivity of many crops is declining due to decline in soil fertility status, imbalanced fertilizer use, lack of knowledge on micro and secondary fertilizers etc. Efficiency of major nutrients is increased in presence of micronutrients (Mehta 1974). There exists a narrow gap between the deficiency and toxicity level. micronutrients and recommendation without soil testing can lead to anomalies. Global Positioning System (GPS) based, soil sampling can provide a basis for developing sitespecific nutrient management via soil fertility maps. In Odisha visual symptoms of deficiency / toxicity of some secondary and micronutrients on crops have been observed at various locations. Hence, a systematic study was conducted to generate information on extent of secondary and micronutrient deficiency or toxicity areas under different soil types and the matic maps have been genrated for different nutrients under GIS environment .

*Corresponding Author Email: bjena8763@gmail.com

\section{Materials and Methods}

\section{Study area}

Kandhamal, a tribal dominated district occupies a central position in the Geo-Political map of Odisha. It lies between $83^{\circ} 30^{1} \mathrm{E}$ to $84^{\circ} 48^{1} \mathrm{E}$ longitude and between $19^{\circ}$ $34^{1} \mathrm{~N}$ to $20^{\circ} 54^{1} \mathrm{~N}$ latitude in agro climatic zone of subregion Eastern Ghats and part of Eastern Plateau. It has a total geographical area of $8021 \mathrm{Sq} \mathrm{Km}$ with an average annual rainfall of $1597 \mathrm{~mm}$ (62.9). The average minimum and maximum temperatures are $1^{\circ}$ in December to $35^{\circ} \mathrm{C}$ respectively.

\section{Soil Sampling}

Grid sampling was done at $1 \times 1 \mathrm{~km}$ distance ensuring minimum 25 samples from each administrative block. The latitude, longitude and elevation at each sampling site were recorded using a hand held GPS and 595 georeferenced surface soil samples were collected from 12 blocks of the district. 
Soil Analysis

Soil samples were air dried, processed, passed through $2 \mathrm{~mm}$ sieve for analysis of nutrients. $\mathrm{pH}$ and EC were measured in 1: 2.5 soil water ratio $(\mathrm{w} / \mathrm{v})$ suspension using $\mathrm{pH}$ meter and $\mathrm{EC}$ meter respectively. Soil OC content was estimated by Walkley and Black (1934) method, Exchangeable Ca by EDTA titration method (Page et al. 1982). Available sulphur was determined spectrophotometrically as described by (Chesnin and Yien (1951). The micronutrient ( $\mathrm{Mn}, \mathrm{Fe}, \mathrm{Zn}, \mathrm{Cu}$ ) from soils were extracted with 0.005 Diethylene Triamine Penta Acetic acid (DTPA) as per method out lined by Lindsey and Norvell (1978). Hot water soluble boron was estimated as per the method outlined by Berger and Trough (1939). Data were subjected to descriptive analysis.

\section{Results and Discussion}

Data on basic parameters like $\mathrm{pH}, \mathrm{EC}, \mathrm{OC}$ are presented in Table 1. The $\mathrm{pH}$ ranged from 4.06 to 8.560 Electrical conductivity of these soils ranged from 0.004 to $0.959 \mathrm{dS} \mathrm{m}^{-1}$. Organic carbon content of soils ranged from 0.02 to $3.9 \%$.

Available $\mathrm{SO}_{4}^{-}{ }_{5}^{-}$varied from $0.38-202.96 \mathrm{mg} \mathrm{kg}^{-1}$ with a mean value of $8.77 \mathrm{mg} \mathrm{kg}^{-1}$ (Table 2) and was deficient in 82.5 percent sample.

In general soils are sufficient in $\mathrm{Fe}, \mathrm{Mn}$ and $\mathrm{Cu}$. Nearly $3.2 \%$ soils showed $\mathrm{Cu}$ deficiency in Khajuripada (2\%) and Raikia (20\%). The Fe content in soils ranged from $0.012-405.2 \mathrm{mg} \mathrm{kg}^{-1}$ with mean value of $81.98 \mathrm{mg} \mathrm{kg}^{-1}$. The DTPA- $\mathrm{Cu}$ content ranged from 0.04 to $4.16 \mathrm{mg} \mathrm{kg}^{-1}$ with mean value of $1.048 \mathrm{mg} \mathrm{kg}^{-1}$. The $\mathrm{Mn}$ content ranged from 1.2 to $400.56 \mathrm{mg} \mathrm{kg}^{-1}$. DTPA $\mathrm{Zn}$ content in soils ranged from 0.017 to $32.77 \mathrm{mg} \mathrm{kg}^{-1}$ with mean value of $1.099 \mathrm{mg} \mathrm{kg}^{-1}$. $\mathrm{Zn}$ deficiency was observed in all blocks of the district. (33.45\%). Hot water soluble boron status of soils ranged from 0.03 to $3.56 \mathrm{mg} \mathrm{kg}^{-1}$, with mean value of $0.38 \mathrm{mg} \mathrm{kg}^{-1}$, with deficiency of $79.66 \%$ percent soil samples.

It may be summarized that soils of the district are sufficient in $\mathrm{Fe}, \mathrm{Mn}, \mathrm{Cu}$ but deficient in $\mathrm{S}, \mathrm{B}$ and $\mathrm{Zn}$. The deficiency was in the order of $\mathrm{S}(82.5 \%)>\mathrm{B}(79.7 \%)>\mathrm{Zn}$ $(33.45 \%)>\mathrm{Cu}(3.2 \%)>\mathrm{Fe}(0.36 \%)$. High deficiency of $\mathrm{S}$ and $B$ in Kandhamal soils might be attributed to high altitude upland (Alfisols) leading to leaching of anionic nutrients.

Based on the above results digitized soil fertility map for sulphur, boron, zinc, copper, manganese and iron were prepared (Fig. 1 through 6). 
Table 1. pH, EC and OC in soils of Kandhamal district

\begin{tabular}{|c|c|c|c|c|}
\hline Block nam e & $\begin{array}{c}\text { No. of } \\
\text { samples }\end{array}$ & $\begin{array}{c}\mathrm{pH} \\
(1: 2.5)\end{array}$ & $\begin{array}{c}E C \\
\left(d S ~ m^{-1}\right)\end{array}$ & $\begin{array}{l}\mathrm{OC} \\
(\%)\end{array}$ \\
\hline Khajuripada & 50 & $4.92-7.06$ & $\begin{array}{c}0.012-0.44 \\
(0.07)\end{array}$ & $\begin{array}{c}0.18-2.81 \\
(0.76)\end{array}$ \\
\hline Phulbani & 75 & $\begin{array}{c}4.53-7.5 \\
(5.79)\end{array}$ & $\begin{array}{c}0.013-0.233 \\
(0.06)\end{array}$ & $\begin{array}{c}0.1-2.71 \\
(0.71)\end{array}$ \\
\hline Phiringia & 74 & $\begin{array}{c}4.88-7.92 \\
(5.83)\end{array}$ & $\begin{array}{c}0.011-0.795 \\
(0.09)\end{array}$ & $\begin{array}{c}0.08-1.66 \\
(0.64)\end{array}$ \\
\hline Raikia & 40 & $\begin{array}{c}4.86-7.29 \\
(5.75)\end{array}$ & $\begin{array}{c}0.018-0.44 \\
\quad(0.08)\end{array}$ & $\begin{array}{c}0.039-1.90 \\
(0.62)\end{array}$ \\
\hline Tikabali & 21 & $\begin{array}{c}4.71-7.43 \\
(5.91)\end{array}$ & $\begin{array}{c}0.028-0.476 \\
(0.09)\end{array}$ & $\begin{array}{c}0.16-3.90 \\
(0.72)\end{array}$ \\
\hline G. Udayagiri & 38 & $\begin{array}{c}4.78-6.86 \\
(5.88)\end{array}$ & $\begin{array}{c}0.016-0.18 \\
(0.05)\end{array}$ & $\begin{array}{c}0.23-1.69 \\
(0.84)\end{array}$ \\
\hline Nuagaon & 31 & $\begin{array}{c}4.5-7.02 \\
(5.83)\end{array}$ & $\begin{array}{c}0.024-0.6 \\
(0.10)\end{array}$ & $\begin{array}{c}0.31-1.59 \\
(0.63)\end{array}$ \\
\hline Baliguda & 24 & $\begin{array}{r}4.4-7.3 \\
(5.53)\end{array}$ & $\begin{array}{c}0.025-0.57 \\
(0.12)\end{array}$ & $\begin{array}{c}0.21-1.16 \\
(0.61)\end{array}$ \\
\hline Chakapada & 32 & $\begin{array}{c}4.72-6.79 \\
(5.83)\end{array}$ & $\begin{array}{c}0.015-0.303 \\
(0.085)\end{array}$ & $\begin{array}{c}0.18-1.21 \\
(0.560)\end{array}$ \\
\hline Tumudibandha & 25 & $\begin{array}{c}4.89-6.06 \\
(5.55)\end{array}$ & $\begin{array}{c}0.038-0.115 \\
(0.06)\end{array}$ & $\begin{array}{c}0.06-1.42 \\
(0.61)\end{array}$ \\
\hline Daringibadi & 140 & $\begin{array}{c}4.06-7.42 \\
(5.69)\end{array}$ & $\begin{array}{c}0.004-0.948 \\
(0.09)\end{array}$ & $\begin{array}{c}0.06-1.79 \\
(0.75)\end{array}$ \\
\hline Kotagarh & 45 & $\begin{array}{c}5.05-8.56 \\
(5.99)\end{array}$ & $\begin{array}{c}0.015-0.959 \\
(0.14)\end{array}$ & $\begin{array}{c}0.02-0.99 \\
(0.50)\end{array}$ \\
\hline Total & 595 & $\begin{array}{c}4.06-8.56 \\
(5.78)\end{array}$ & $\begin{array}{c}0.004-0.959 \\
(0.08)\end{array}$ & $\begin{array}{c}0.02-3.9 \\
(0.68)\end{array}$ \\
\hline
\end{tabular}

Number within parenthesis denote mean values. 


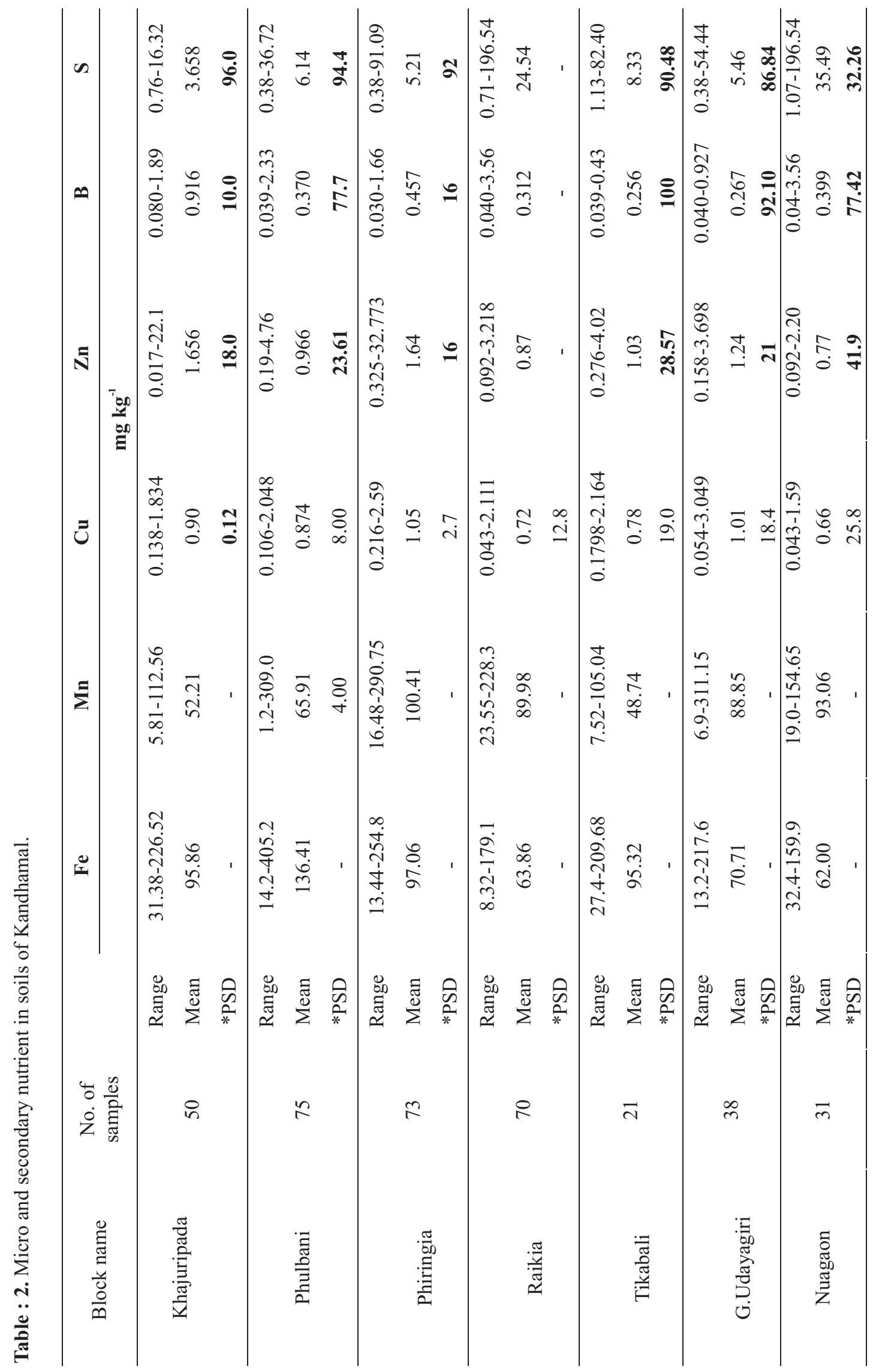




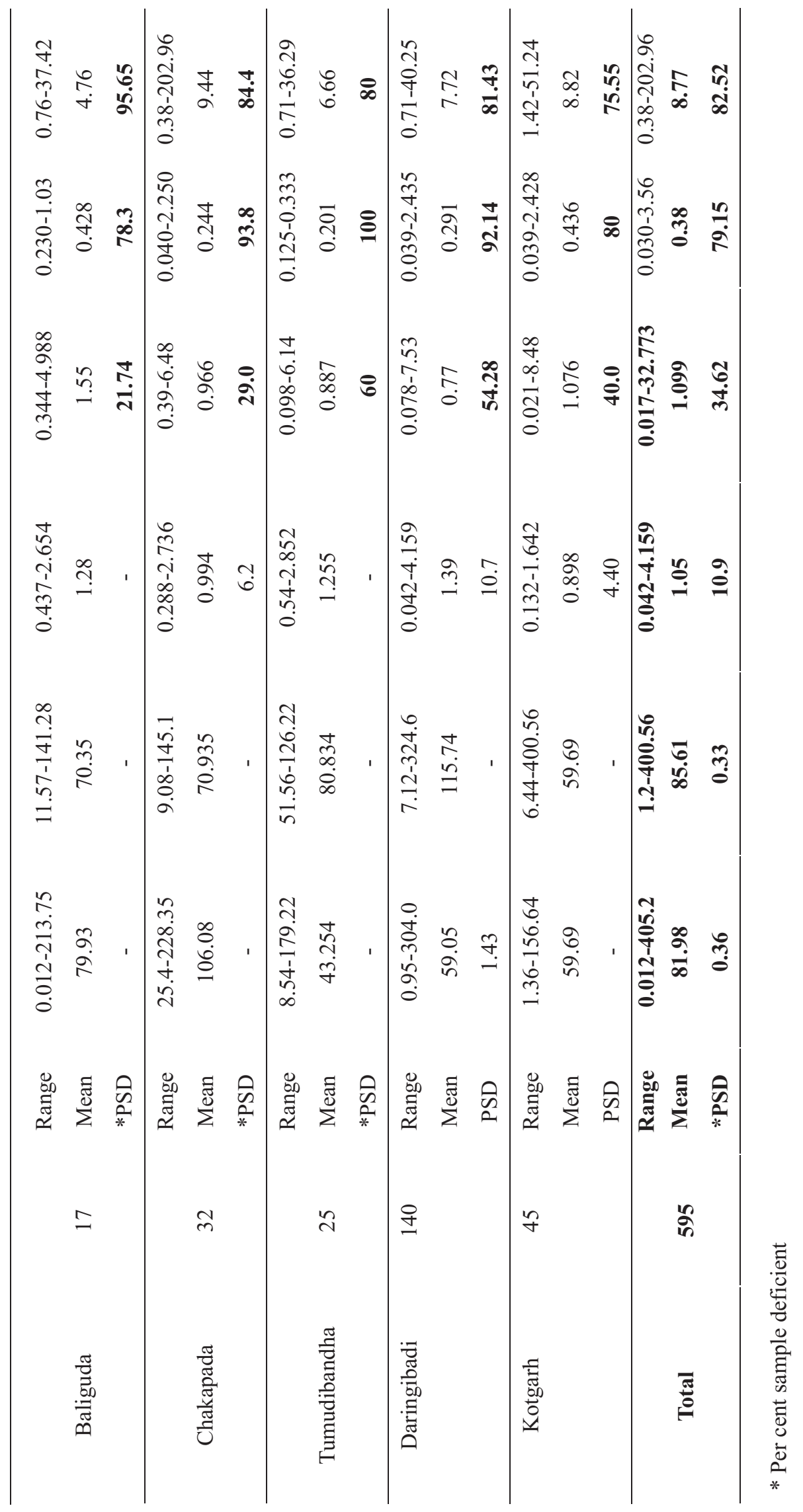


Out of 595 samples 159 samples were analyzed for exchangeable $\mathrm{Ca}^{+2}$, the range and mean are presented in table 3. It was found that exchangeable $\mathrm{Ca}^{+2}$ content varied from $0.75-15.4 \mathrm{cmol}\left(\mathrm{p}^{+}\right) \mathrm{kg}^{-1}$ with mean value of 4.62 $\operatorname{cmol}\left(\mathrm{P}^{+}\right) \mathrm{kg}^{-1}$ and it was above critical limit.

Table 3. Block wise Exchangeable Ca content of Kandhamal soils

\begin{tabular}{clccc}
\hline \multicolumn{1}{c}{ Block } & Sample & $\begin{array}{c}\text { Range } \\
{\left[\mathbf{c m o l}\left(\mathbf{P}^{+}\right) \mathbf{~ k g}^{-1}\right]}\end{array}$ & Mean \\
\hline 1 & Khajuripada & 28 & $1.2-12.4$ & 5.52 \\
2 & Phulbani & 9 & $1.13-5.38$ & 2.75 \\
3 & Phiringia & 21 & $4.2-12.2$ & 9.01 \\
4 & Raikia & 8 & $3.6-7.4$ & 5.25 \\
5 & Tikabali & 10 & $3.8-8.6$ & 5.86 \\
6 & G.Udayagiri & 12 & $2.6-6.6$ & 3.73 \\
7 & Nuagaon & 10 & $0.75-2.63$ & 1.44 \\
8 & Baliguda & 9 & $3.8-6.2$ & 5.07 \\
9 & Chakapada & 11 & $4.40-15.40$ & 7.33 \\
10 & Tumudibandha & 8 & $1.20-4.40$ & 2.30 \\
11 & Daringibadi & 24 & $1.0-8.0$ & 4.31 \\
12 & Kotgarh & 9 & $0.75-6.25$ & 2.89 \\
\hline
\end{tabular}

Multinutrient deficiency was observed at many grid points. together in almost $40 \%$ samples, while $23 \%$ samples showed Table 4 shows that boron and sulphur deficiency occurred common deficiency of zinc, boron and sulphur together.

Table 4. Extent of Multimicronutrient deficiency in Kandhamal district

\begin{tabular}{cc}
\hline Nutrient & Deficiency (\%) \\
\hline $\mathrm{B}+\mathrm{S}$ & 39.83 \\
$\mathrm{Zn}+\mathrm{S}$ & 3.60 \\
$\mathrm{Zn}+\mathrm{B}$ & 5.70 \\
$\mathrm{Zn}+\mathrm{B}+\mathrm{S}$ & 22.86 \\
\hline
\end{tabular}

The interrelationship between various micronutrients and other soil properties were analyzed and presented in table 5. It indicated negative correlation of $\mathrm{pH}$ with soil micronutrients viz. $\mathrm{Fe}, \mathrm{Mn}, \mathrm{Zn}$ and positive correlation of extractable $\mathrm{Cu}, \mathrm{S}$ with $\mathrm{OC}$ of soil. 
Table 5. Correlation coefficient of different soil parameters with extractable secondary and micronutrients of Kandhamal soils

\begin{tabular}{rrrrrrrrrr}
\hline & pH & EC & OC & Fe & Mn & Cu & Zn & B & S \\
\hline pH & 1 & & & & & & & & \\
EC & 0.407 & 1 & & & & & & & \\
OC & 0.155 & 0.499 & 1 & & & & & & \\
Fe & $\mathbf{- 0 . 4 7 3}$ & 0.005 & 0.050 & 1 & & & & & \\
Mn & -0.183 & 0.041 & 0.283 & 0.415 & 1 & & & & \\
Cu & 0.008 & 0.445 & $\mathbf{0 . 6 2 6}$ & 0.165 & 0.250 & & & & \\
Zn & -0.119 & 0.165 & 0.250 & $\mathbf{0 . 3 4 9}$ & 0.168 & $\mathbf{0 . 3 8 7}$ & 1 & & \\
B & 0.017 & 0.173 & 0.031 & 0.152 & 0.099 & 0.026 & 0.181 & 1 & \\
S & 0.140 & 0.369 & $\mathbf{0 . 3 9 5}$ & 0.009 & 0.071 & $\mathbf{0 . 3 4 9}$ & 0.141 & 0.126 & 1 \\
\hline
\end{tabular}

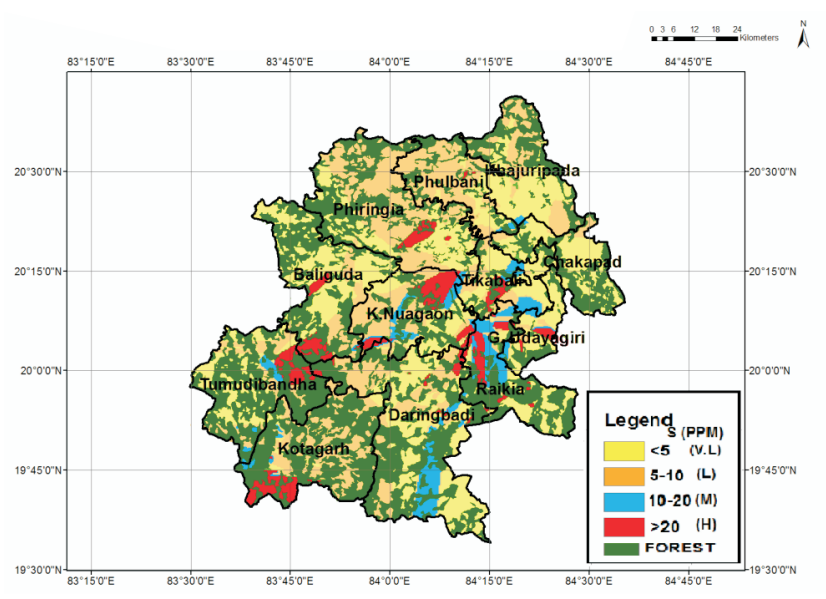

Fig.1 Digitized sulphur content map

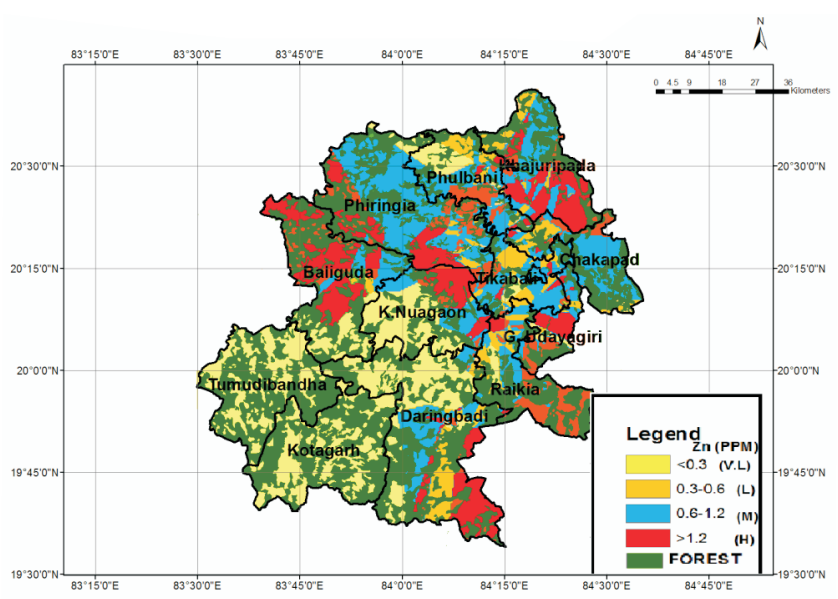

Fig. 3 Digitized zinc map

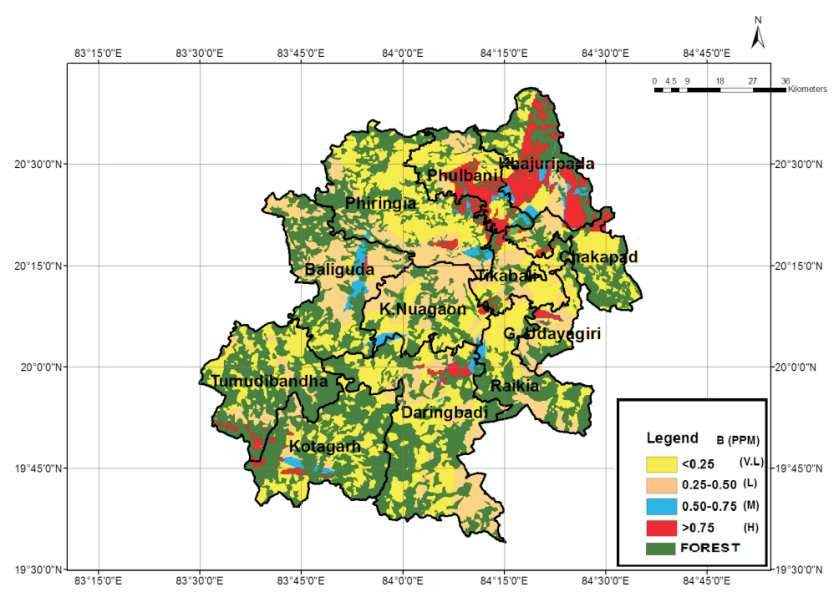

Fig.2 Digitized Boron content map

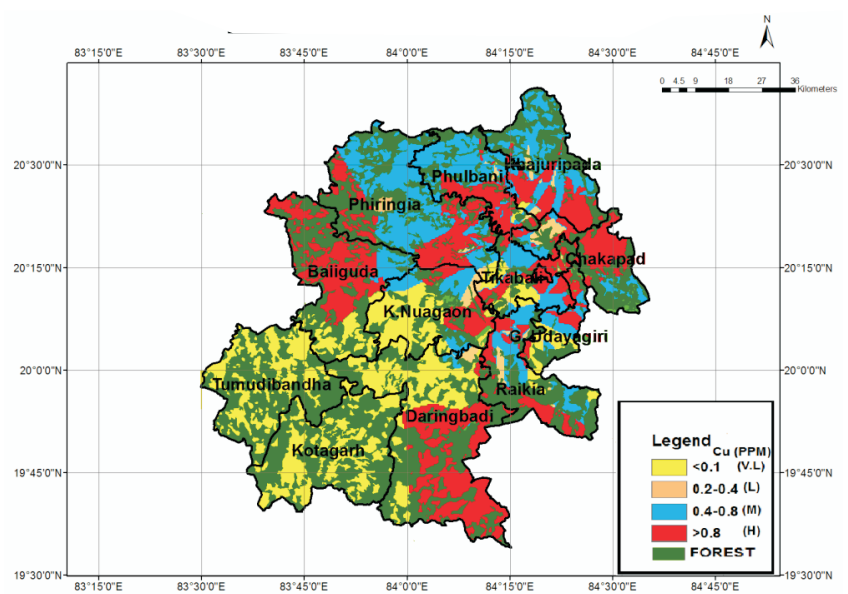

Fig.4 Digitized copper map 


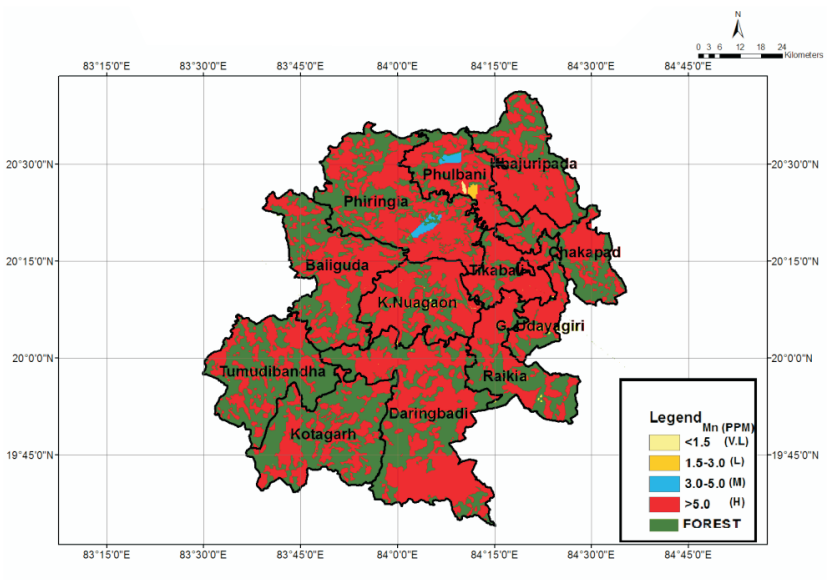

Fig.5 Digitized manganese map

\section{Conclusion}

Kandhamal soils exhibited high sulphur deficiency followed by boron and zinc. Hence crop management practices should include application of these maturites for higher crop production. Application of S @ 20-40 kg through gypsum, phosphogypsum, bentonite sulphur is recommended along with NPK fertilizers for higher production. Soil fertility maps developed can help farmers, scientists, agriculture officers, etc. in crop and soil management and serve as a reference nutrient map.

\section{References}

Berger, K. C. and Truog, E. (1939). Boron determination in soils and plants using the quinalizarin reaction. Industrial and Engineering Chemistry. Analytical Edition 11, 540-545.

Chesnin L. and Yien C.H. (1951). Turbidimetric determination of available sulphate. Soil Science Society of America Proceedings 15, 149-151.

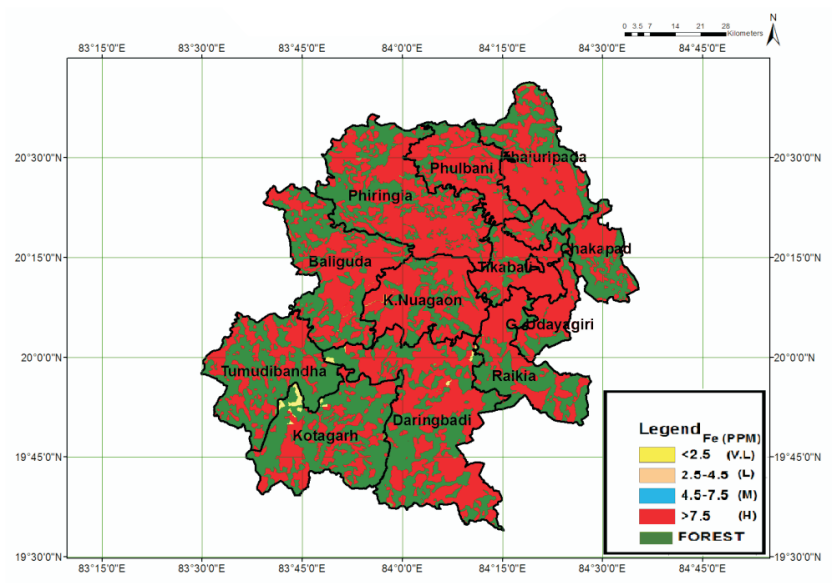

Fig.6 Digitized iron map

John, M.K., Chuah, H.H. and Neufeld, J.H. (1975). Application of improved azomethine- $\mathrm{H}$ method to the determination of boron in soils and plants. Analytical Letters 8, 559-568.

Lindsay, W.L. and Norvell W.A. (1978). Development of a DTPA soil test for zinc, iron, manganese, and copper. Soil Science Society of America Journal. 42:421-428.

Mehta B.V. (1974). Secondary and micronutrients and nutrient interaction should be considered in balanced fertilization for higher production. Journal of the Indian Society of Soil Science, 22, 91102.

Page, A.1, Miller, R.H., Keeney, D.R., Baker, D.E., Roseoc Ellis, J.R. and Rhodes, J. (1982). Methods of soil analysis Part 2: chemical and Microbiological Properties, $2^{\text {nd }}$ Edition Agronomy Monograph No. 9. American society of Agronamy and Soil Science Society America Madison, Wisconsin, USA.

Walkley, A. and Black, I.A. (1934). Rapid titration method of organic carbon of soils. Soil Science. 37: 29-33.

Received : December, 2015

Accepted : April, 2016 